\title{
PELAYANAN JASA ATAS DIMENSI EMPAT KEPUASAN KONSUMEN
}

\author{
Lulu Indriaty \\ Sekolah Tinggi Ilmu Ekonomi YAPIS MERAUKE \\ Email: lulu.indriaty@stieyapismerauke.ac.id
}

\begin{abstract}
Abstrak
Masyarakat semakin sadar akan pentingnya transportasi. Hal tersebut dapat dilihat dari ketatnya persaingan dalam dunia bisnis sepeda motor. Sebagai perusahaan yang bergerak dalam barang dan jasa, maka tingkat kepuasan konsumen sangat berpengaruh terhadap laba perusahaan. Tujuan dari penelitian ini adalah untuk mengetahui bagaimana tingkat kepuasan konsumen pada Bengkel Yamaha Merauke yang dilihat dari 4 dimensi penentu kualitas jasa yaitu dimensi tangibles (bukti fisik), reliability (kehandalan), assurance (jaminan), ressponsiveness (daya tanggap).

Uji instrumen pengumpul data di lakukan dengan menggunakan uji validitas dan reliabilitas untuk mengetahui kuesioner valid atau tidak. Dan teknik analisis di lakukan dengan menggunakan mean arithmetic dan diagram kartesius, dengan dengan menjumlahkan semua nilai data pengamatan kemudian dibagi dengan banyaknya data dan kemudian akan di peroleh rata-rata dari rata-rata tingkat kepentingan dan tingkat kinerja yang selanjutnya akan di masukkan ke dalam diagram kartesius untuk mengetahui tingkat kepuasan konsumen.
\end{abstract}

Kata kunci: Pemasaran Jasa, Dimensi Kualitas Pelayanan, Kepuasan Konsumen, Tangibles, Reliability, Assurance, Ressponsiveness.

\section{PENDAHULUAN}

Industri jasa pada saat ini merupakan sektor ekonomi yang sangat besar dan tumbuh sangat pesat. Pertumbuhan tersebut selain disebabkan oleh pertumbuhan jenis jasa yang sudah ada sebelumnya, juga disebabkan oleh munculnya jenis jasa baru sebagai akibat dari tuntutan dan perkembangan teknologi. Hal ini menjadi dasar bagi industri jasa untuk melakukan kegiatan pemasaran jasa. Proses pemasaran itu sendiri adalah proses tentang bagaimana pengusaha dapat mempengaruhi konsumen agar para konsumen tersebut menjadi tahu, senang lalu membeli produk yang ditawarkan dan menjadi puas sehingga mereka akan selalu membeli produk perusahaan itu (Gitosudarmo, 2001). Nelson dan Chan (2004) menyatakan, satu hal yang menjadi pertimbangan utama perusahaan dalam mempertahankan pelanggannya, yakni karena semakin mahalnya biaya perolehan pelanggan baru dalam situasi kompetisi yang semakin ketat. Untuk menciptakan kondisi seperti itu, Lodh (2007) menyarankan perusahaan harus merancang strategi yang baik untuk digunakan sebagai usaha mendorong dan menciptakan perasaan puas pelanggannya sehingga dapat menciptakan pelanggan yang loyal. Kepuasan yang dirasakan oleh para konsumen dicapai melalui perancangan strategi pemasaran yang baik dan tepat oleh lembaga tersebut. 
Seiring dengan perkembangan jaman dan teknologi khususnya pada bidang otomotif, banyak pebisnis lokal maupun mancanegara menjadikan nya sebagai. sebuah bisnis yang menjanjikan sehingga terjadi persaingan yang cukup ketat antar pelaku bisnis otomotif. Di Indonesia sendiri banyak perusahaan motor terkemuka yang banyak diminati oleh konsumen seperti: Honda, Suzuki, Kawasaki, Yamaha, dan lain-lain. Selain menjual motor, semua perusahaan motor juga menyediakan jasa service dan ganti spare part motor yang sesuai dengan produk masing-masing perusahaan. Pokok bahasan kali ini adalah kepuasan konsumen terhadap kualitas pelayanan di bengkel Yamaha Merauke. Perusahaan Yamaha mempunyai visi dan misi menjadi perusahaan distributor motor, produk dan jasa pendukungnya yang memiliki jaringan pemasaran terbesar di Indonesia dan menjadi perusahaan yang terpercaya, meliputi sumber daya manusia, keuangan, teknologi \& informasi, dan sumber daya fisik.

Salah satu fasilitas jasa penunjang untuk menigkatkan kepuasan konsumen adalah membuat bengkel resmi Yamaha untuk mendukung penjualan serta sarana untuk memuaskan pelayanan konsumen sepeda motor Yamaha. Konsumen berharap dengan membeli produk motor Yamaha kebutuhan perawatan dan pemeliharaan sepeda motornya jadi lebih terjaga dengan adanya bengkel resmi dari Yamaha. Karena di mata masyarakat awam bengkel resmi pasti memiliki standard dan ketentuan pula yang pastinya menjamin kepuasan pelanggan. Salah satu strategi pemasaran perusahaan Yamaha adalah mendirikan beberapa bengkel resmi di Merauke, salah satunya yang terletak di daerah Merauke. Strategi ini terbilang cukup bagus mengingat di merauke adalah kawasan yang ramai.

Pada bidang otomotif, khususnya pada bengkel Yamaha produk yang di tawarkan adalah jasa servis dan penjualan spare part khusus sepeda moto Yamaha. Di penelitian ini yang akan di bahas adalah dimensi kualitas pelayanan yang mencakup tangibles (bukti fisik), reliability (kehandalan), assurance (jaminan), responsiveness (daya tanggap). terhadap kepuasan pelanggan.

\section{RUMUSAN MASALAH}

1. Kualitas layanan di batasi pada 4 dimensi kualitas pelayanan yaitu : tangibles (bukti fisik), reliability (kehandalan), assurance (jaminan), responsiveness (daya tanggap).

2. Penelitian ini dibatasi pada konsumen bengkel Yamaha Merauke yang menggunakan layanan jasa lebih dari 2 kali.

\section{TEORI DAN PENGEMBANGAN HIPOTESIS}

Banyak yang berpikiran bahwa kegiatan pemasaran hanya sebatas menjual produk, namun sebenarnya kegiatan pemasaran lebih luas dari penjualan dan penjualan merupakan bagian dari kegiatan pemasaran. Achmad Buchory (2010) mengemukakan, pengertian pemasaran adalah suatu proses sosial dan manajerial antara individu dan kelompok untuk memenuhi kebutuhan dan keinginan melalui penciptaan, penawaran dan pertukaran (nilai) produk dengan yang lain. Dalam peranannya strategi pemasaran mencakup setiap usaha untuk mencapai kesesuaian antara perusahaan dengan lingkungannya dalam rangka mencari pemecah atas masalah. Penentuan dua pertimbangan pokok yakni bisnis apa yang dimasuki masa mendatang dan kedua bagaimana bisnis yang dipilih tersebut dapat dijalankan dengan sukses dalam lingkungan persaingan atas dasar perspektif distribusi, produk, harga, dan promosi yang telah lama dikenal sebagai bauran pemasaran (marketing 
mix). Ali Hasan (2009) berpendapat sebagai ilmu pengetahuan, marketing merupakan ilmu pengetahuan yang objektif, yang diperoleh dengan penggunaan instrumen-instrumen tertentu untuk mengukur kinerja aktifitas bisnis dalam membentuk, mengembangkan, mengarahkan pertukaran yang saling menguntungkan dalam jangka panjang antara produsen dan konsumen. Dari pengertian di atas maka dapat disimpulkan bahwa pemasaran berhubungan dengan penciptaan keinginan dan kebutuhan konsumen. menciptakan, mengkomunikasikan, dan memberikan nilai serta kepuasan kepada konsumen adalah inti pemikiran dan praktek pemasaran moderen. Dua sasaran pemasaran yang utama adalah menarik konsumen dan menjanjikan nilai yang unggul dan mempertahankan konsumen saat ini dengan memberikan kepuasan. Strategi pemasaran yang tepat memberikan kekuatan pada perusahaan untuk bersaing dengan perusahaan lainnya sehingga memberikan keuntungan pada perusahaan tersebut. Menurut Payne (2000) mengemukakan jasa adalah suatu kegiatan yang memiliki beberapa unsur ketakberwujudan yang berhubungan dengannya melibatkan beberapa interaksi dengan konsumen atau dengan property dalam kepemilikannya, dan tidak menghasilkan transfer kepemilikan. Zeithami dan Bitner (2000) mengemukakan definisi jasa adalah seluruh aktivitas ekonomi dengan output selain produk dalam pengertian fisik, dikonsumsi dan diproduksi pada saat bersamaan, memberikan nilai tambah dan secara prinsip tidak berwujud bagi pembeli pertamanya. Dari pengertian pemasaran dan jasa di atas, maka pemasaran jasa dapat disimpulkan bahwa sebagai kegiatan proses sosial dan manajerial yang mana individu-individu dan kelompok-kelompok mendapatkan apa yang dibutuhkan dan inginkan melalui penciptaan penawaran yang pada dasarnya tidak berwujud fisik dan tidak mengakibatkan kepemilikan apapun mempunyai nilai tambah yang tidak berwujud pula pada saat dibeli.

Industri jasa pada saat ini merupakan sektor ekonomi yang sangat besar dan pertumbuhannya pun sangat pesat. Pertumbuhan tersebut selain diakibatkan oleh pertumbuhan jenis jasa yang sudah ada sebelumnya, juga disebabkan oleh munculnya jenis jasa baru, sebagai akibat dari tuntutan dan perkembangan zaman. Dipandang dari segi konteks globalisasi, pesatnya pertumbuhan bisnis jasa antar negara ditandai dengan meningkatnya intensitas pemasaran lintas negara serta terjadinya aliansi berbagai penyedia jasa di dunai.

Perkembangan tersebut pada akhirnya mempu memberikan tekanan yang kuat terhadap perombakan regulasi, khususnya pengenduran proteksi dan pemanfaatan teknologi baru yang secara langsung akan berdampak pada menguatnya kompetisi dalam industri. Kondisi ini secara langsung menghadapkan para pelaku bisnis kepada permasalahan persaingan usaha yang semakin tinggi. Mereka dituntut untuk mampu mengidentifikasikan bentuk persaingan yang akan dihadapi, menetapkan berbagai standar kinerjanya serta mengenali secara baik para pesaingnya Hurriyati (2010).

Dinamika yang terjadi pada sektor jasa terlihat dari perkembangan berbagai industri seperti layanan antar surat, layanan paket barang, pengiriman/transfer uang, yang kini semakin menyadari perlunya peningkatan orientasi kepada pelanggan atau konsumen. Perusahaan manufaktur kini juga telah menyadari perlunya elemen jasa pada produknya sebagai upaya peningkatan competitive advantage bisnisnya. Implikasi penting dari fenomena ini adalah semakin tingginya tingkat persaingan, sehingga diperlukan manajemen pemasaran jasa yang berbeda dibandingkan dengan pemasaran tradisional (barang) yang telah dikenal 
selama ini. Menurut Payne yang dikutif oleh Hurriyati (2010) bahwa pemasaran jasa merupakan suatu proses mempersepsikan, memahami, menstimulasi dan memenuhi kebutuhan pasar sasaran yang dipilih secara khusus dengan menyalurkan sumber-sumber sebuah organisasi untuk memenuhi kebutuhan tersebut. Dengan demikian, manajemen pemasaran jasa merupakan proses penyelarasan sumber-sumber sebuah organisasi terhadap kebutuhan pasar. Pemasaran memberi perhatian pada hubungan timbal balik yang dinamis antara produk dan jasa perusahaan, keinginan dan kebutuhan pelanggan serta kegiatan- kegiatan para pesaing. Menurut Kotler (2009) secara umum kepuasan adalah perasaan senang atau kecewa seseorang yang berasal dari perbandingan antara kesannya terhadap kinerja suatu produk dan harapan-harapannya. Terciptanya kepuasan konsumen dapat memberikan manfaat, diantaranya hubungan antara perusahaan dengan pelanggannya menjadi harmonis, memberikan dasar yang baik bagi pembeli ulang dan terciptanya loyalitas konsumen, serta dapat juga membentuk rekomendasi dari mulut ke mulut yang menguntungkan bagi perusahaan. Lupiyoadi (2008) Menyatakan bahwa konsep loyalitas lebih mengarah kepada prilaku dibandingkan dengan sikap dan seorang konsumen yang loyal akan memperlihatkan prilaku pembelian yang didefinisikan sebagai pembelian yang teratur. Lovelock (2007) mengatakan bahwa pelanggan yang loyal memiliki karakteristik; melakukan pembelian atau menggunakan jasa secara berulang-ulang, tetap setia berlangganan pada sebuah perusahaan dalam jangka panjang, merekomendasikan produk atau jasa yang telah digunakan kepada pihak lain, dan menunjukan kekebalan dari daya tarik produk atau jasa sejenis dari pesaing.

Konsep hubungan antara bauran pemasaran jasa terhadap kepuasan dan loyalitas dapat dilihat memalui beberapa kajian-kajian empiris yang bila dijelaskan sebagai berikut, Produk yang mampu membuat para konsumennya menjadi puas serta memberikan dampak terhadap rasa loyal disebabkan karena adanya pengembangan-pengembangan yang dilakukan oleh para pemasar seperti, menyediakan variasi produk beragam yang sesuai dengan kebutuhan konsumen yang berbeda-beda, merancang produk agar memiliki citra atau nama yang cukup dapat dibanggakan oleh para konsumen dalam menggunakannya, serta penyediaan atau penyampaian fungsi dan manfaat produk dengan diiringi kualitas pelayanan yang memuaskan ditujukan ke para konsumennya juga sangat dapat mempengaruhi tingkat kepuasan para konsumen. Dari penelitian yang dilakukan oleh Suwarni (2011), Sudarsono (2009), Adnan (2006), dan Johannes (2009) dapat memperkuat konsep adanya pengaruh yang positif dari produk terhadap kepuasan dan loyalitas. Penetapan kebijakan harga yang terjangkau dari kemampuan yang dimiliki konsumen serta tingkat harga yang sesuai dengan kualitas dan manfaat barang atau jasa yang ditawarkan diharapkan mampu memberikan orientasi yang baik ke para konsumen sehingga dapat menimbulkan rasa puas dan loyal .

Hasil dari penelitian yang dilakukan oleh Suwarni (2011), Haryoso (2009) dan Wijayanti (2009) mampu mendukung konsep tentang hubungan harga terhadap kepuasan, dimana hasil dari penelitiannya menyatakan bahwa terdapat pengaruh positif variabel harga terhadap kepuasan dan loyalitas.Promosi yang dilakuakan dengan berbagai kegiatan promosi seperti mengadakan periklanan, kegiatan promosi penjualan, pemasaran pribadi, serta menjalin hubungan dengan masyarakat/pelanggan secara aktif merupakan promosi konsumen untuk mencari tahu keberadaan produk atau jasa yang ditawarkan hal tersebut 
juga mampu untuk menciptakan kepuasan dan loyalitas konsumen. Penelitian yang dilakukan oleh Johannes (2009), Soegoto (2011), Manulu (2007), Foster (2010) dan Triwardani (2009) dapat mendukung konsep pengaruh promosi terhadap kepuasan yang menyatakan bahwa kegiatan promosi memiliki pengaruh positif terhadap kepuasan dan loyalitas Dalam upaya memenuhi kepuasan konsumen, perusahaan memang dituntut kejeliannya untuk mengetahui pergeseran kebutuhan dan keinginan konsumen yang hampir setiap saat berubah. Pembeli akan bergerak setelah membentuk persepsi terhadap nilai penawaran, kepuasan sesudah pembelian tergantung dari kinerja penawaran dibandingkan dengan harapannya.

Fandy Tjiptono (2004) mendefinisikan kepuasan pelanggan sebagai evaluasi secara sadar atau penilaian kognitif menyangkut apakah kinerja produk relatif bagus atau jelek atau apakah produk bersangkutan cocok atau tidak cocok dengan tujuan/ pemakaiannya.

Menurut Philip Kotler (2000) dalam Principle of Marketing bahwa Kepuasan Konsumen adalah hasil yang dirasakan oleh pembeli yang mengalami kinerja sebuah perusahaan yang sesuai dengan harapannya. Pelanggan merasa puas kalau harapan mereka terpenuhi, dan merasa amat gembira kalau harapan mereka terlampaui. Pelanggan yang puas cenderung tetap loyal lebih lama, membeli lebih banyak, kurang peka terhadap perubahan harga dan pembicaraannya menguntungkan perusahaan.

Menurut teori Supranto dalam jurnal Susanti (2012), kepuasan konsumen merupakan label yang digunakan oleh konsumen untuk meringkas suatu himpunan aksi atau tindakan yang terlihat, terkait dengan produk atau jasa. Sedangkan menurut jurnal Bachtiar (2011), kepuasan konsumen merupakan perasaan positif konsumen yangberhubungan dengan produk / jasa selama menggunakan atau setelah menggunakan jasa atau produk. Kesesuaian yang mengalami ketidaksesuaian antara harapan dengan kinerja aktual jasa atau produk maka konsumen berada pada diskonfirmasi. Jadi dapat disimpulkan dari beberapa pengertian tersebut menurut para ahli, bahwa kepuasan konsumen adalah tingkat perasaan seseorang ketika menerima produk atau jasa yang ditawarkan serta membandingkan kinerja atas produk atau jasa yang diterima dengan harapan yang dimiliki. Dalam rangka menciptakan kepuasan pelanggan, produk yang ditawarkan organisasi/perusahaan harus berkualitas. Kualitas mencerminkan semua dimensi penawaran produk yang menghasilkan manfaat (benefits) bagi pelanggan. Ada beberapa pendapat mengenai dimensi kualitas pelayanan, antara lain Parasuraman, Zeithaml, dan Berry dalam Saleh (2010) yang melakukan penelitian khusus terhadap beberapa jenis jasa dan berhasil mengidentifikasi sepuluh faktor utama yang menentukan kualitas jasa. Kesepuluh faktor tersebut adalah:

1. Reliability, mencakup dua hal pokok, yaitu konsistensi kerja (performance) dan kemampuan untuk dipercaya (dependbility). Hal ini berarti perusahaan memberikan jasanya secara tepat semenjak saat pertama. Selain itu juga berarti bahwa perusahaan yang bersangkutan memenuhi janjinya, misalnya menyampaikan jasanya sesuai dengan jadwal yang disepakati.

2. Responsiveness, yaitu kemauan atau kesiapan para karyawan untuk memberikan jasa yang dibutuhkan pelanggan.

3. Competence, artinya setiap orang dalam suatu perusahaan memiliki keterampilan dan pengetahuan yang dibutuhkan agar dapat memberikan jasa tertentu. 
4. Accessibility, meliputi kemudahan untuk menghubungi dan ditemui. Hal ini berarti lokasi fasilitas jasa yang mudah dijangkau, waktu menunggu yang tidak terlalu lama, saluran komunikasi perusahaan mudah dihubungi, dan lain-lain.

5. Courtesy, meliputi sikap sopan santun, respek, perhatian, dan keramahan yang dimiliki para kontak personal.

6. Communication, artinya memberikan informasi kepada pelanggan pada bahasa yang dapat mereka pahami, serta selalu mendengarkan saran dan keluhan pelanggan.

\section{METODE PENELITIAN}

Penelitian ini berlokasi di bengkel resmi Yamaha yang ber alamat di Jl. Merauke Raya, Kec. Depok, Sleman No.168, Daerah Istimewa Merauke. Subyek penelitian adalah tempat variabel melekat. Variabel penelitian adalah objek penelitian. Sementara itu Sukardi (2010) menyatakan populasi adalah semua anggota kelompok manusia, binatang, peristiwa, atau benda yang tinggal bersama dalam satu tempat dan secara terencana menjadi target kesimpulan dari hasil akhir suatu penelitian. Di pihak lain, Sisworo dalam Mardalis (2009) mendefenisikan populasi sebagai sejumlah kasus yang memenuhi seperangkat kriteria yang ditentukan peneliti. Dalam penelitian ini populasi nya adalah seluruh konsumen bengkel Yamaha Merauke Sampel adalah sebgian atau wakil dari pupulasi yang diteliti (Arikunto, 2006). Mardalis (2009) menyatakan sampel adalah contoh, yaitu sebagian dari seluruh individu yang menjadi objek penelitian. Jadi sampel adalah contoh yang diambil dari sebagain populasi penelitian yang dapat mewakili populasi.

Walaupun yang diteliti adalah sampel, tetapi hasil penelitian atau kesimpulan penelitian berlaku untuk populasi atau kesimpulan penelitian digeneralisasikan terhadap populasi. Yang dimaksud menggeneralisasikan adalah mengangkat kesimpulan penelitian dari sampel sebagai sesuatu yang berlaku bagi populasi. Sampel dalam penelitian ini adalah dengan menggunakan teknik sampling dengan mempertimbangkan kriteria tertentu yakni konsumen yang telah menggunakan jasa bengkel Yamaha Merauke lebih dari dua kali. Berdasarkan hasil perhitungan yang telah diperoleh, maka dapat diketahui jumlah sampel yang akan diambil dalam penelitian ini adalah 100 responden.

\section{HASIL DAN PEMBAHASAN}

Uji validitas adalah tingkat keandalah dan kesahihan alat ukur yang digunakan. Intrumen dikatakan valid berarti menunjukkan alat ukur yang dipergunakan untuk mendapatkan data itu valid atau dapat digunakan untuk mengukur apa yang seharusnya di ukur (Sugiyono, 2004). Dengan demikian, instrumen yang valid merupakan instrumen yang benar-benar tepat untuk mengukur apa yang hendak di ukur. Kuesioner dikatakan valid apabila $r$ hitung (Corrected Item Total Corelation) $>r$ tabel dan kuesioner dikatakan tidak valid apabila $r$ hitung $<r$ tabel. Berdasarkan hasil uji validitas terhadap butir-butir pertanyaan pada atribut kepentingan tangibles, maka hasil yang diperoelh $r$ hitung $>r$ tabel, maka dapat disimpulkan bahwa butir-butir pertanyaan pada tingkat kepentingan tangibles adalah valid.

Berdasarkan hasil uji validitas terhadap butir-butir pertanyaan pada atribut kepentingan reliability, maka hasil yang diperoleh $r$ hitung $>r$ tabel, maka dapat disimpulkan bahwa butir-butir pertanyaan pada tingkat kepentingan reliability adalah valid. Berdasarkan hasil uji validitas terhadap butir-butir pertanyaan pada atribut kepentingan assurance (jaminan), maka hasil yang diperoleh $r$ hitung $>r$ tabel, maka dapat disimpulkan bahwa butir-butir 
pertanyaan pada tingkat kepentingan assurance adalah valid. Berdasarkan hasil uji validitas terhadap butir-butir pertanyaan pada atribut kepentingan ressponsiveness (daya tanggap), maka hasil yang diperoleh $r$ hitung $>r$ tabel, maka dapat disimpulkan bahwa butir-butir pertanyaan pada tingkat kepentingan ressponsiveness adalah valid.

Berdasarkan hasil uji validitas terhadap butir-butir pertanyaan pada atribut tingkat kinerja tangibles, maka hasil yang diperoelh $r$ hitung $>r$ tabel, maka dapat disimpulkan bahwa butir-butir pertanyaan pada tingkat kepentingan tangibles adalah valid. Berdasarkan hasil uji validitas terhadap butir-butir pertanyaan pada atribut tingkat kinerja reliability, maka hasil yang diperoelh $r$ hitung $>r$ tabel, maka dapat disimpulkan bahwa butir-butir pertanyaan pada tingkat kepentingan reliability adalah valid. Berdasarkan hasil uji validitas terhadap butir-butir pertanyaan pada atribut tingkat kinerja assurance, maka hasil yang diperoelh $r$ hitung > $r$ tabel, maka dapat disimpulkan bahwa butir-butir pertanyaan pada tingkat kepentingan assurance adalah valid.

Uji reliabilitas berguna untuk menetapkan apakah instrumen yang dalam hal ini kuesioner dapat digunakan lebih dari satu kali, paling tidak oleh responden yang sama akan menghasilkan data yang konsisten. Dengan kata lain, reliabilitas instrumen mencirikan tingkat konsistensi. Kuesioner dikatakan reliabel apabila nilai alpha cronbach lebih besar dari 0,6 dimana pada pengujian reliabilitas ini menggunakan bantuan komputer program SPSS versi 17. Berdasarkan hasil perhitungan diperoleh nilai korelasi antara harapan dan kinerja pada atribut Tangibles ( bukti fisik ), Reliability (Keandalan), Assurance (Jaminan), Responsiveness (Daya tanggap).

Berdasarkan tabel di atas dapat diketahui bahwa variabel yang diuji memiliki koefisien reliabel alpha chronbach lebih besar dari 0,60, maka dapat disimpulkan bahwa butir-butir pertanyaan reliabel. Pada atribut tangibles 0,719 , pada atribut reliability 0,736 , pada atribut assurance 0,652, dan yang terakhir pada atribut ressponsiveness adalah 0,7630. Berdasarkan tabel di atas dapat diketahui bahwa variabel yang diuji memiliki koefisien reliabel alpha chronbach lebih besar dari 0,60, maka dapat disimpulkan bahwa butir-butir pertanyaan reliabel, pada atribut tangibles 0,750 , pada atribut reliability 0,721 , pada atribut assurance 0,651, dan yang terakhir pada atribut ressponsiveness adalah 0,675.

Responden dapat diketahui bahwa mayoritas usia yang menggunakan layanan jasa Bengkel Yamaha Merauke adalah usia antara 23-28 tahun yaitu sebanyak 71 orang atau $71 \%$, kemudian usia antara 35-40 sebanyak 13 orang atau $13 \%$, kemudian usia antara 17-22 tahun yaitu sebanyak 11 orang, dan paling sedikit adalah usia antara 29-34 tahun yaitu sebanyak 5 orang atau $5 \%$. mayoritas jenis kelamin yang menggunakan layanan jasa Bengkel Yamaha Merauke adalah berjenis kelamin laki-laki yaitu sebanyak 74 orang atau 74 $\%$, kemudian untuk pengguna jasa yang berjenis kelamin perempuan berjumlah 26 orang atau $26 \%$.

penialian konsumen pada atribut tangibles yang paling tinggi adalah pada atribut lokasi yang strategis dengan rata-rata 3,94 yaitu penting, posisi kedua pada fasilitas ruang tunggu dengan rata- rata 3,75 yaitu penting, posisi ketiga pada kelengkapan peralatan service dan spare part dengan rata-rata 3,70 yaitu penting, dan terakhir pada kebersihan dan kenyamanan ruang tunggu 3,68 yaitu penting. penialian konsumen pada atribut reliability yang paling tinggi adalah pada atribut ketepatan waktu pelayanan dengan rata-rata 4,00 yaitu penting, posisi kedua pada ketepatan dalam memenuhi standar layanan sesuai 3,98 
yaitu penting, posisi ketiga pada prosedur service sesuai standart pabrik Yamaha tunggu dengan rata-rata 3,92 yaitu penting, dan terakhir pada ketelitian dalam pelayanan service 3,88 yaitu penting.

Penialian konsumen pada atribut assurance yang paling tinggi adalah pada atribut kemampuan dan kecekatan kerja pegawai dalam melayani konsumen dengan rata-rata 4,02 yaitu penting, posisi kedua pada kesopanan dan keramahan pegawai saat dihubungi atau melayani konsumen dengan rata-rata 3,95 yaitu penting, posisi ketiga pada pengetahuan dan kemampuan pegawai dalam menyelesaikan permasalahan konsumen dengan rata- rata 3,86 yaitu penting. penialian konsumen pada atribut ressponsivenes yang paling tinggi adalah pada atribut ketepatan dalam memenuhi standar layanan dengan rata-rata 4,04 yaitu penting, posisi kedua pada ketelitian dalam pelayanan service dengan rata-rata 3,75 yaitu penting, posisi ketiga pada kesiap-siagaan pegawai untuk melayani konsumen dengan segera dengan rata-rata 3,86 yaitu penting, dan yang terakhir adalah prosedur service sesuai standart pabrik Yamaha dengan rata-rata 3,66 yaitu penting.

Penialian konsumen pada atribut tangibles yang paling tinggi adalah pada atribut lokasi yang strategis dengan rata-rata 4,02 yaitu penting, posisi kedua pada fasilitas ruang tunggu dengan rata- rata 3,98 yaitu penting, posisi ketiga pada kelengkapan peralatan service dan spare part dengan rata-rata 3,95 yaitu penting, dan terakhir pada kebersihan dan kenyamanan ruang tunggu 3,88 yaitu penting.Penialian konsumen pada atribut reliability yang paling tinggi adalah pada atribut ketepatan dalam memenuhi standar layanan dengan rata-rata 4,01 yaitu penting, posisi kedua dengan masing-masing rata-rata 3,78 adalah atribut ketelitian dalam pelayanan service dan atribut prosedur service sesuai standart pabrik Yamaha yaitu penting, dan terakhir pada ketepatan waktu pelayanan 3,88 yaitu penting.

Penialian konsumen pada atribut assurance yang paling tinggi adalah pada atribut kemampuan dan kecekatan kerja pegawai dalam melayani konsumen dengan rata-rata 3,90 yaitu penting, posisi kedua pada kesopanan dan keramahan pegawai saat dihubungi atau melayani konsumen dengan rata-rata 3,84 yaitu penting, dan posisi ketiga pada pengetahuan dan kemampuan pegawai dalam menyelesaikan permasalahan konsumen dengan rata- rata 3,82 yaitu penting. penialian konsumen pada atribut ressponsivenes yang paling tinggi adalah pada atribut ketelitian dalam pelayanan service dengan rata-rata 4,06 yaitu penting, posisi kedua pada prosedur service sesuai standart pabrik Yamaha dengan rata-rata 3,99 yaitu penting, dan posisi ketiga dengan masing-masing rata-rata 3,90 adalah atribut kesiap-siagaan pegawai untuk melayani konsumen dengan segera dan atribut ketepatan dalam memenuhi standar layanan yaitu penting.

Menurut Supranto (2004), Diagram Kartesius adalah suatu bangunan yang dibagi atas empat bagian yang dibatasi oleh dua buah garis yang berpotongan tegak lurus pada titiktitik $(X, Y)$. X merupakan rata-rata dari rata-rata skor tingkat pelaksanaan atau kepuasan pelanggan seluruh faktor atau atribut, $X$ merupakan tingkat kinerja perusahaan yang dapat memberikan kepuasan para pelanggan, sedangkan $Y$ adalah rata- rata dari rata- rata skor tingkat kepentingan seluruh faktor yang mempengaruhi kepuasan pelanggan. Inti penggunaan Diagram Kartesius adalah untuk mengetahui di titik atau area mana pelanggan puas dan di titik atau area mana pelanggan belum puas atau kecewa terhadap kinerja perusahaan. 
Tabel 1

Rata-Rata X dan Y

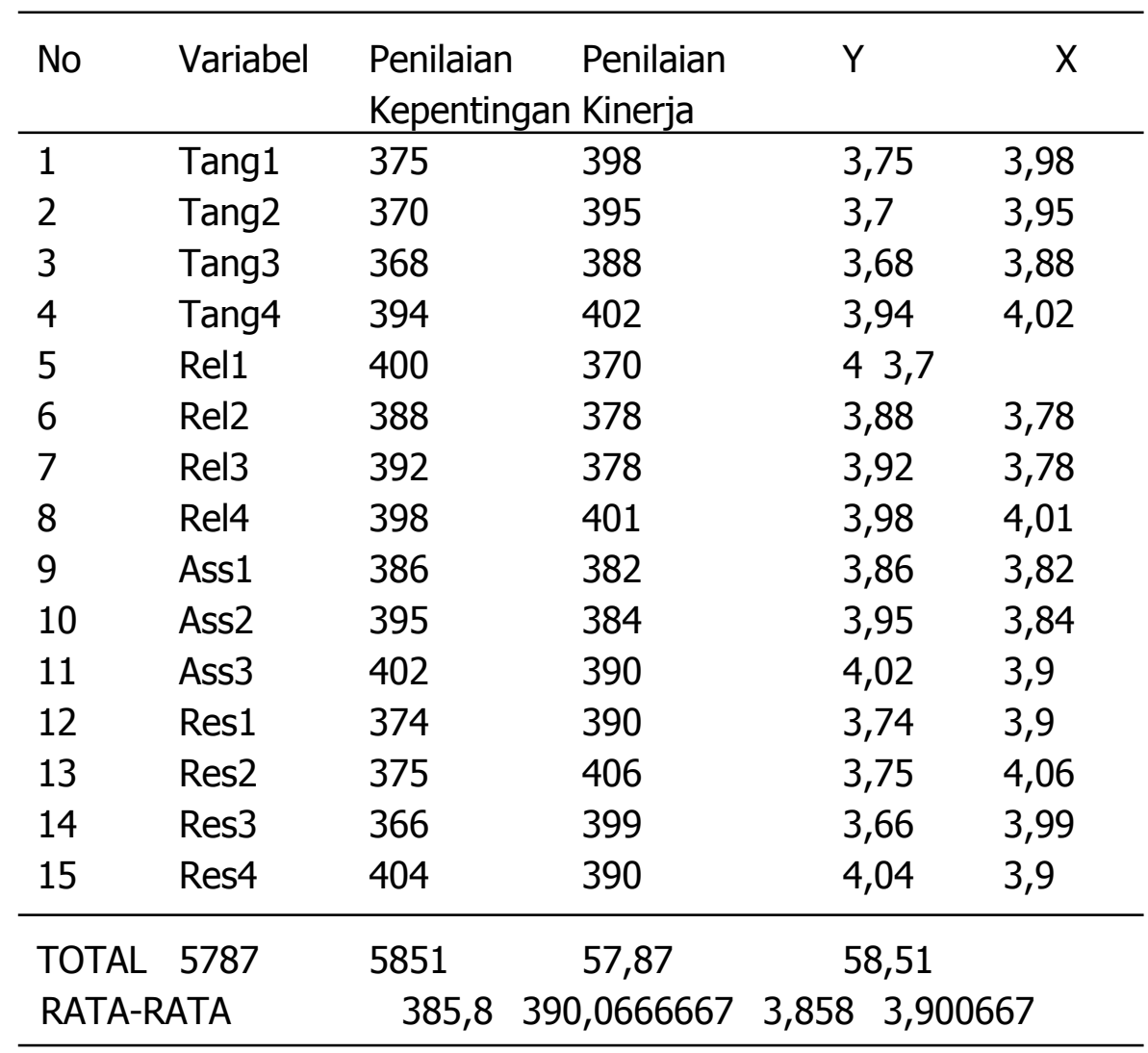

Menurut tabel di atas kemudian dapat di peroleh rata-rata dari rata-rata masing-masing penilaian, yang kemudian akan di masukkan kedalam diagram kartesius dan hasilnya adalah sebagai berikut:

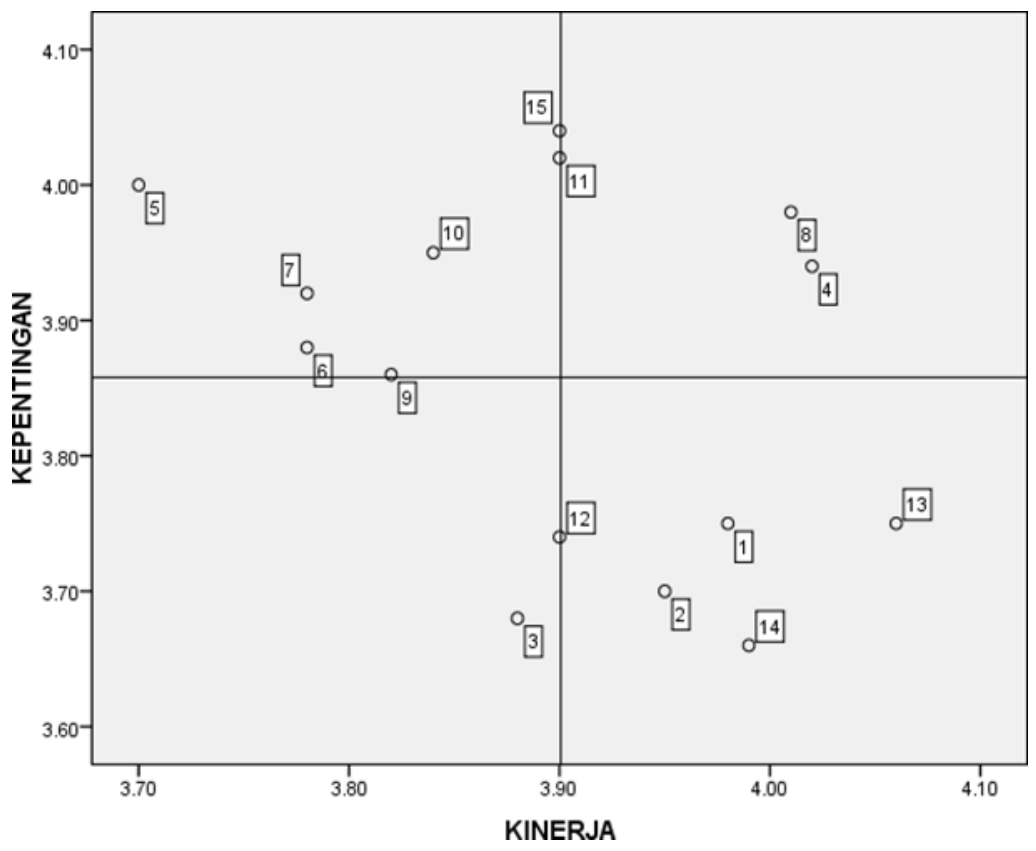


Berdasarkan diagram di atas, maka hasil yang diperoleh adalah beberapa atribut pelayanan yang masuk kuadran A, B, C dan kuadran D. Berikut keterangan beberapa atribut pelayanan yang masuk pada kuadran:

Pada kuadran A menunjukkan atribut atau faktor dianggap penting oleh konsumen, namun manajemen belum mampu melaksanakan sesuai harapan konsumen sehingga tidak memuaskan konsumen. Ada beberapa atribut yang termasuk dalam kuadran A, adalah:

a. Ketepatan waktu pelayanan

Berdasarkan hasil penelitian pada ketepatan waktu pelayanan diketahuai bahwa masih kurang memuaskan konsumen, dikarenakan ketepatan waktu pelayanan yang di berikan tidak sesuai dengan yang telah dijanjikan sebelumnya.

b. Ketelitian dalam pelayanan service

Berdasarkan hasil penelitian pada ketelitian dalam pelayanan service diketahuai bahwa masih kurang memuaskan, dikarenakan masih terdapat karyawan/ pelayan service yang kurang teliti dalam pengecekan kendaraan konsumen.

c. Prosedur service sesuai standart pabrik Yamaha

Berdasarkan hasil penelitian pada prosedur service sesuai standart pabrik Yamaha diketahuai bahwa masih kurang memuaskan, dikarenakan standart pada service bagian pengecekan masih belum memenuhi prosedur standart service pabrik Yamaha hal ini di sebabkan oleh beberapa karyawan atau mekanik pada bagian pengecekan masih belum berpengalaman atau mekanik baru.

d. Pengetahuan dan kemampuan pegawai dalam menyelesaikan permasalahan konsumen Berdasarkan hasil penelitian pada pengetahuan dan kemampuan pegawai dalam menyelesaian permasalahan konsumen diketahuai bahwa masih kurang memuaskan, dikarenakan mekanik kurang begitu memamahami keluhan konsumen.

e. Kesopanan dan keramahan pegawai saat dihubungi atau melayani konsumen

Berdasarkan hasil penelitian Kesopanan dan keramahan pegawai saat dihubungi atau melayani konsumen diketahuai bahwa masih kurang memuaskan, karena pegawai atau mekanik yang sibuk melayani banyak konsumen sehingga terkadang pegawai atau mekanik tidak memperhatikan atau menyapa konsumen.

Kuadran B, menunjukkan atribut yang mempengaruhi kepuasan konsumen, dan perusahaan telah melaksanakan sesuai dengan harapan konsumen sehingga konsumen merasa puas. Ada beberapa atribut yang termasuk dalam kuadran B, adalah:

a. Lokasi yang strategis

Berdasarkan hasil penelitian lokasi yang strategis diketahui bahwa sudah memuaskan konsumen, hal ini di karenakan lokasi bengkel yang strategis terletak di daerah yang ramai, sehingga mudah di akses oleh konsumen

b. Ketepatan dalam memenuhi standar layanan sesuai dengan kebutuhan konsumen.

Berdasarkan hasil penelitian ketepatan dalam memenuhi standar layanan sesuai dengan kebutuhan konsumen diketahui bahwa sudah memuaskan konsumen, hal ini di karenakan mekanik selalu melakukan service sesuai dengan kemauan dan keinginan konsumen.

c. Kemampuan dan kecekatan kerja pegawai dalam melayani konsumen Berdasarkan hasil penelitian kemampuan dan kecekatan kerja pegawai 
dalam melayani konsumen diketahui bahwa sudah memuaskan konsumen, hal ini di karenakan kemampuan kerja yang di berikan oleh mekanik kepada konsumen di lakukan sesuai kemampuan mekanik.

d. Menyesuaikan pelayanan dengan kebutuhan konsumen

Berdasarkan hasil penelitian menyesuaikan pelayanan dengan kebutuhan konsumen diketahui bahwa sudah memuaskan konsumen, hal ini di karenakan mekanik mampu memenuhi kebutuhan konsumen sesuai dengan keinginan dan kemauan konsumen

Kuadran $\mathrm{C}$ ini menunjukkan atribut atau faktor dianggap tidak begitu penting oleh konsumen, namun dilaksanakan dengan cukup oleh manajemen, sehingga cukup memuaskan bagi konsumen. Atribut yang termasuk ke dalam kuadran $\mathrm{C}$, adalah :

a. Kebersihan dan kenyamanan ruang tunggu

Berdasarkan hasil penelitian pada kebersihan dan kenyamanan ruang tunggu cukup memuaskan, karena ruang tunggu yang terdapat pada bengkel Yamaha merauke terawat dengan baik sehingga konsumen merasa nyaman.

Kuadran $D$ ini menunjukkan atribut atau faktor dianggap tidak begitu penting oleh konsumen, namun dilaksanakan dengan sangat baik oleh manajemen sehingga sangat memuaskan konsumen. Ada beberapa atribut yang termasuk ke dalam kuadran $D$, adalah:

a. Fasilitas ruang tunggu

Berdasarkan hasil penelitian pada fasilitas ruang tunggu sangat baik dan sangat memuaskan, karena pada fasilitas ruang tunggu terdapat fasilitas seperti televisi dan free wifi, sehingga konsumen dapat menungu dengan nyaman.

b. Kelengkapan peralatan service dan spare part

Berdasarkan hasil penelitian pada kelengkapan peralatan service dan spare part sangat baik dan sangat memuaskan, karena peralatan service dan spare part pada bengkel Yamaha merauke sudah memenuhi standart pabrik Yamaha.

c. Kesiap-siagaan pegawai untuk melayani konsumen dengan segera Berdasarkan hasil penelitian pada kesiap-siagaan pegawai untuk melayani konsumen dengan segera sangat baik dan sangat memuaskan, hal ini disebabkan oleh kesiapan pegawai untuk melayani konsumen dengan segera pada saat konsumen datang.

d. Keseriusan/kesungguhan mekanik dalam menanggapi keluhan konsumen

Berdasarkan hasil penelitian pada keseriusan/kesungguhan pegawai dalam menanggapi keluhan konsumen sangat baik dan sangat memuaskan, dikarenakan pegawai atau mekanik menanggapi keluhan konsumen dengan serius, sehingga konsumen merasa di perhatikan.

e. Keseriusan/kesungguhan pegawai saat menjalankan tugas melayani konsumen

Berdasarkan hasil penelitian pada keseriusan/kesungguhan pegawai saat menjalankan tugas melayani konsumen sangat baik dan sangat memuaskan, hal ini di karenakan kesungguhan pelayanan yang di berikan oleh pegawai.

\section{KESIMPULAN}

Berdasarkan hasil penelitian dimensi kualitas pelayanan jasa yang di lakukan di bengkel Yamaha merauke di peroleh kesimpulan sebagai berikut:

1. Ada beberapa atribut yang membuat konsumen merasa tidak puas, yaitu: Ketepatan waktu pelayanan, ketelitian dalam pelayanan service, prosedur service sesuai standar pabrik Yamaha, pengetahuan dan kemampuan pegawai dalam menyelesaikan 
permasalahan konsumen, kesopanan dan keramahan pegawai saat dihubungi atau melayani konsumen.

2. Ada beberapa atribut yang membuat konsumen merasa puas, yaitu: Lokasi yang strategis, ketepatan dalam memenuhi standar layanan sesuai dengan kebutuhan konsumen, kemampuan dan kecekatan kerja pgawai dalam melayani konsumen, menyesuaikan degan kebutuhan konsumen.

3. Atribut yang membuat konsumen merasa cukup puas, yaitu : kebersihan dan kenyamanan ruang tunggu.

4. Ada beberapa atribut yang membuat konsumen merasa sangat puas, yaitu : fasilitas ruang tunggu, kelengkapan peralatan service dan sparepart, kesiapan pegawai untuk melayani konsumen dengan segera, keseriusan ekanik dalam menanggapi keluhan konsumen.

\section{SARAN PENELITIAN YANG AKAN DATANG}

Berdasarkan kesimpulan diatas maka di peroleh beberapa saran untuk pegawai Bengkel Yahama Merauke, yaitu :

1. Perlu adanya peningkatan dalam ketepatan waktu pelayanan, dengan cara memberikan pelayanan kepada konsumen sesuai dengan janji yang di berikan.

2. Perlu adanya peningkatan dalam ketelitian dalam pelayanan service, dengan melakukan pengecekan secara detail setelah selesai melakukan service atau penggantian spare part.

3. Perlu adanya peningkatan dalam prosedur service sesuai standart pabrik Yamaha, dengan dengan melakukan penyuluhan tentang proserdur service standart pabrik Yamaha yang benar kepada seluruh pegawai atau mekanik.

4. Perlu adanya peningkatan dalam pengetahuan dan kemampuan pegawai dalam menyelesaikan permasalahan konsumen, dengan meningkatkan wawasan pegawai atau mekanik tentang segala bentuk permasalahan sepeda motor sehingga pegawai atau mekanik mampu menyelesaikan permasalahan konsumen dengan baik.

5. Perlu adanya peningkatan dalam kesopanan dan keramahan pegawai saat dihubungi atau melayani konsumen, dengan melakukan penyuluhan kepada semua pegawai atau mekanik tentang kesopanan dan keramahan dalam melayani konsumen secara rutin pada pagi hari sebelum membuka bengkel

\section{DAFTAR PUSTAKA}

Hurriyati, Ratih, 2005 " Bauran Pemasaran Dan Loyalitas Konsumen ", Cetakan Pertama, Bandung: Penerbit Alfabet .

Alma, Buchari, 2002 " Manajemen Pemasaran dan Pemasaran Jasa ", Alfabeta, Bandung. 2007 Ko Lovelock, Christhoper H, "Service Marketing ", Third Edition, Prentice HallInternational Inc., New Jersey.

Kotler, Phillip, 2007 " Marketing Management: Analysis, Planning, Implementation, and Control ", Millenium Edition,. A division of Simon \& Scuster, Inc.

Mathis , R.L , dan J.H , Jakson . 2000. Manajemen Sumber Daya Manusia . Jakarta: Salemba Empat. 
Adrian, Payne, 2000 " Pemasaran Jasa "(Terj. Fandy Tjiptono), Andi Offset, Merauke.

Kotler, Philip. 2002. Manajemen Pemasaran (Edisi Milenium). Jakarta: PT Prenhalindo.

M. Nur Nasution. 2004. Manajemen Jasa Terpadu. Bogor: Ghalia Indonesia.

Rambat Lupiyoadi. 2004. Manajemen Pemasaran Jasa : Teori dan Pratek. Jakarta: PT salemba Empat.

Kotler, Philip dan A.B Susanto. 2000. Manajemen Pemasaran Jasa Di Indonesia, Analisis Perencanaan, Implementasi dan pengendalian (Edisi pertama). Jakarta: Salemba Empat. 